\title{
EARTHWORMS AS SOIL QUALITY INDICATORS: LOCAL AND SCIENTIFIC KNOWLEDGE IN RICE MANAGEMENT SYSTEMS
}

\author{
Ana Cláudia Rodrigues de LIMA ${ }^{1 *}$ \& Lijbert BRUSSAARD ${ }^{2}$ \\ ${ }^{1}$ Federal University of Pelotas, Campus Universitário s/n, Caixa Postal 354, 96010-900, Pelotas, RS, \\ Brazil. E-mail: anacrlima@hotmail.com.*Corresponding author. \\ ${ }^{2}$ Wageningen University, P.O. Box 47, 6700 AA, Wageningen, The Netherlands. E-mail: lijbert. \\ brussaard@wur.nl.
}

Lima, A. C. R. \& L. Brussaard. 2010. Earthworms as soil quality indicators: local and scientific knowledge in rice management systems. Acta Zoológica Mexicana (n.s.), Número Especial 2: 109-116. ABSTRACT. Farmers from Camaquã, Rio Grande do Sul, Brazil, were shown to have a holistic view of the quality of the soil they are cultivating. Progress towards sustainable land management will come from the synergy of both local and formal scientific knowledge. However, the literature on soil quality largely fails to address such integration. The objective of the present work was to highlight the potential use of earthworms in indicating soil quality from a rice farmers' perspective and using a formal scientific assessment in Camaquã. From a study of local knowledge of farmers and soil analysis it was shown that earthworms are an important component of soil quality. Although the farmers considered that earthworms indicated the quality of their soils, they hardly used them as indicators, due to their limited observation of these animals. A decision-support system to evaluate the options for using earthworms in sustainable management is needed in rice production systems.

Keywords: Soil biota, indigenous knowledge, bioindicators, Brazil, rice production systems.

Rodrigues Lima, A. C. R. \& L. Brussaard. 2010. Lombrices de tierra como bioindicadoras de la calidad de los suelos: conocimiento local y científico en sistemas de manejo del arroz. Acta Zoológica Mexicana (n.s.), Número Especial 2: 109-116.

RESUMEN. Se demostró que los agricultores de Camaquã, Rio Grande do Sul, Brasil, tienen una visión holística de la calidad del suelo que están cultivando. El progreso hacia el manejo sostenible debe estar acompañado de una sinergia entre el conocimiento local y científico. Sin embargo, la literatura sobre la calidad del suelo generalmente ignora ésta integración. El objetivo de este trabajo fue de resaltar el uso potencial de las lombrices de tierra como indicadoras de la calidad del suelo en cultivos de arroz irrigado desde la perspectiva del agricultor y usando una evaluación científica de la calidad del suelo en Camaquã. A partir del conocimiento local y usando los resultados del análisis del suelo, se mostró que las lombrices son un importante componente de la calidad del suelo. Aunque los agricultores consideraron que las lombrices podrían indicar la calidad de sus suelos, difícilmente las usaron para este propósito, debido a su limitada observación de éstos animales. Por lo tanto, se precisa de un sistema de apoyo para facilitar las decisiones de uso de las lombrices de tierra en el manejo sostenible del suelo en sistemas de producción de arroz.

Palabras clave: Biota del suelo, conocimiento tradicional, bioindicadores, Brasil, arrozales.

Recibido: 16/05/2008; aceptado: 08/01/2010. 


\section{INTRODUCTION}

The sustainability of agricultural practices can be evaluated using soil quality indicators (Doran \& Zeiss 2000). Recent studies have suggested that soil biological indicators can serve as early and sensitive indicators of effects of soil management (Bloem \& Breure 2003, Brussaard et al. 2004, Govaerts et al. 2006). Due to their important functional role in soil ecosystems and their sensitivity to soil properties and plants, earthworms have been used for the assessment of contaminated soils (Römbke et al. 2007), of soil quality in different agroecosystems (Nunes et al. 2007) as well as to assess their responses to changes in some biochemical, biological and physical soil properties (Paoletti et al. 1991).

There has been an increasing recognition of the notion that, next to formal scientific knowledge, local knowledge of farmers can yield insight into soil quality, based on their ability to perceive differences between and within fields (Roming et al. 1996, Lefroy et al. 2000, Ali 2003, Ericksen \& Ardón 2003). However, although benefits of local knowledge include high local relevance to complex environmental interactions, local definitions and observations can be inaccurate and unsuitable to address environmental change without scientific input (Barrios \& Trejo 2003).

One approach to more objectively assess soil quality is the evaluation of several soil properties simultaneously using statistical procedures that account for correlations. Multivariate statistical methods are used to select a minimum data set (MDS) from large data sets. Various such MDSs have been proposed at plot, field scale (Doran \& Parkin 1996), regional scale (Brejda et al. 2000a,b) and national scales (Sparling \& Schipper 2002). As a result, the concept of a MDS of soil quality indicators has become widely accepted as the minimum needed to effectively monitor soil quality and to simplify interpretation in terms of sustainable land use, while reducing costs.

Rice farmers' perspectives assessed using semi-structured interviews alternated with discussion groups, and formal scientific assessment of soil quality in order to develop a MDS using multivariate statistical analysis of 29 soil properties (Lima et al. 2008) have contributed to an understanding of soil quality in rice production systems in Southern Brazil. However, there has been little investigation on the possibilities and constraints of using earthworms as a soil quality indicator. Therefore, the present work was developed to assess whether earthworms are meaningful to farmers and if they can be used as indicators of soil quality.

\section{MATERIAL AND METHODS}

The area of our study was the "Banhado do Colégio", located in Camaquã county, between latitude $30^{\circ} 48^{\prime}$ and $31^{\circ} 32^{\prime} \mathrm{S}$, and longitude $51^{\circ} 47^{\prime}$ and $52^{\circ} 19^{\prime} \mathrm{W}$ at $39 \mathrm{~m}$ elevation, in the coastal plains area of the state of Rio Grande do Sul, Southern Brazil. 
The predominant soil types are Albaqualfs and Humaquepts (Soil Survey Staff 2006). The main difference between these soils is the clay content in the topsoil (Cunha et al. 2001). The rice management systems generally used in the state are different with respect to intensity of soil tillage and water use: conventional (dry seedbed preparation and sowing, high tillage intensity), pre-germinated (seedbed preparation and sowing on inundated fields, high tillage intensity) and semi-direct (dry seedbed preparation and sowing, low tillage intensity).

Local soil knowledge was explored by semi-structured interviews and discussion groups with 32 farmers. These interviews took place at the farmer's house or in his/ her field. Subsequently, 21 fields ranging from 2 to 500 ha in size were selected for soil sampling from the 32 farmers interviewed. These fields were selected to represent the two soil great groups and the three main regional rice management systems. In each field, five replicate plots, $2 \times 2 \mathrm{~m}$ each, were randomly laid out within an area of 3 ha. In total 105 representative plots were sampled from March to June 2004 (immediately after harvest). In each plot, 20 sub-samples were taken from $0-10 \mathrm{~cm}$ depth across the sampling plot area, bulked and mixed for chemical, microbiological, and physical soil analyses. For some (e.g., bulk density) physical analyses, three undisturbed soil cores $(5 \mathrm{~cm}$ diameter $\times 3 \mathrm{~cm})$ were also obtained from each plot. Earthworms were hand-sorted from a $30 \times 30 \times 30 \mathrm{~cm}$ monolith located in the central area of each plot from the 21 rice fields and 8 adjacent areas (not disturbed in the last 20 years).

After sub-dividing the soil samples into 4 soil textural classes according to clay content $(<20 \%, 20-40 \%, 40-60 \%,>60 \%)$ and 3 rice management systems, a multivariate statistical analysis (factor analysis and discriminant analysis) of 29 soil physical, chemical and biological indicators was performed. Following the factor analysis a stepwise discriminant analysis on all the properties comprising the significant components was carried out. Detailed methods of analysis of the physical, chemical and biological properties studied are given in Lima et al. (2008).

\section{RESULTS}

From the local soil knowledge study, it was found that the majority of regional farmers (97\%) identified earthworms as a good soil quality indicator (Table I).

The statistical approach selected five different soil properties as the most powerful discriminators among soil textural classes and again five as the most powerful discriminators (determined by the value of discriminant coefficient; $p<0.001$ ) among management systems (Table II). Earthworms were one of the soil quality indicators that discriminated management systems. From these analyses we arrived at a MDS consisting of eight significant soil quality indicators, one of which was earthworms, the other ones being available water, bulk density, mean weight diameter, organic matter, $\mathrm{Zn}, \mathrm{Cu}$ and $\mathrm{Mn}$ (Lima et al. 2008). 
Lima \& Brussaard: Earthworms as soil quality indicators

Table I. List and classification of the farmers' soil quality indicators.

\begin{tabular}{lc}
\hline \multicolumn{1}{c}{ Indicator } & \% of farmers who mentioned the indicator \\
\hline Biological & 97 \\
$\quad$ Earthworms & \\
Physical & 43 \\
$\quad$ Friability & \\
Chemical & 57 \\
Organic matter & \\
Plant performance & 67 \\
Yield & 63 \\
Spontaneous vegetation (weeds) & 53 \\
Root development & 43 \\
Rice plant development & 16 \\
Rice plant color & 16 \\
Number of rice tillers & \\
Intrinsic soil characteristics & 87 \\
Soil color & \\
Other & 10 \\
Healthy and good-looking cattle & \\
\hline
\end{tabular}

\section{DISCUSSION}

The local soil knowledge results appear to be the case for many farmers in Southern Brazil, particularly those who adopted no-tillage, beginning in the late 1970's in Paraná State (Brown et al. 2003). In fact, the name "Clube da Minhoca" ("Earthworm club") was given to the first no-till farmer organization in the Campos Gerais Region of that state. However, for the rice farmers the presence or absence of earthworms in the soil was not an important factor in their actual decision making, because their perceptions generally rely on soil indicators that they can easily see and/or experience. Furthermore, most farmers did not know about the presence of significant earthworm populations in their own fields, and assumed that their populations were very low because of the presumed deleterious effects of the irrigated management practices, particularly soil tillage, intensity of water use and, in some cases, herbicide use (by the farmers who apply the semi-direct management system). As two farmers stated: "... earthworms cannot survive in the inundated soil" (Orzeli Reinard), or "... because of the herbicides the soil is dead!" (Antônio Kila Neto).

In contrast, Birang et al. (2003) found that farmers in southern Cameroon used this indicator in their decision-making processes: signs of presence or activity of soil macrofauna (notably earthworms) were used by $42 \%$ of the farmers as an indicator 
Table II. Summary of stepwise discriminant analysis among soil textural classes and management systems (from Lima et al. 2008).

\begin{tabular}{|c|c|c|c|c|c|c|}
\hline & \multicolumn{3}{|c|}{ Soil Textural Classes } & \multicolumn{3}{|c|}{ Management Systems } \\
\hline & \multicolumn{6}{|c|}{ Discriminant Function } \\
\hline & 1 & 2 & 3 & & 1 & 2 \\
\hline Significance & $<0.001$ & $<0.001$ & 0.073 & & $<0.001$ & $<0.001$ \\
\hline Eigenvalue & 6.943 & 0.352 & 0.073 & & 2.373 & 1.493 \\
\hline$\%$ of variance explained & 94.2 & 4.8 & 1.0 & & 61.4 & 38.6 \\
\hline Canonical correlation coefficient & 0.935 & 0.510 & 0.260 & & 0.839 & 0.774 \\
\hline Selected Indicators* & \multicolumn{3}{|c|}{ Discriminant coefficient } & $\begin{array}{c}\text { Selected } \\
\text { Indicators* }\end{array}$ & \multicolumn{2}{|c|}{$\begin{array}{c}\text { Discriminant } \\
\text { coefficient }\end{array}$} \\
\hline $\mathrm{Cu}$ & -0.553 & 0.943 & -1.068 & EN & 0.071 & -0.476 \\
\hline $\mathrm{Zn}$ & 0.075 & -0.354 & 1.391 & $\mathrm{OM}$ & 1.359 & -0.494 \\
\hline $\mathrm{Mn}$ & -0.532 & -0.572 & -0.207 & $\mathrm{Cu}$ & 0.455 & 0.729 \\
\hline $\mathrm{BD}$ & 1.201 & -0.518 & 0.357 & Mn & -1.368 & -0.612 \\
\hline AW & 0.276 & 0.901 & -0.007 & MWD & -0.462 & 0.862 \\
\hline
\end{tabular}

*AW: Available Water, BD: Bulk Density, EN: Earthworm Number, OM: Organic Matter, MWD, Mean Weight Diameter

of the level of soil fertility and in deciding whether the soils under fallow were ready for subsequent cropping. They believed that the yield would be higher in the presence of earthworms.

Although the farmers in our study recognized the potential use of earthworms, in practice they only use soil quality indicators that they could easily observe (e.g. rice plant development, soil colour). Regional farmers only took the topsoil or the tilled layer into account when evaluating the quality of their rice fields. Earthworm species occurring in deeper layers or semi-aquatic earthworms were not considered by farmers because they did not know of their existence. Nonetheless, a sampling of the earthworms in their rice fields and adjacent areas revealed nine species, all new records for the region (Lima \& Rodríguez 2007). Two species were reported for the first time from Rio Grande do Sul and a new native genus and species of Criodrilidae (Guarani camaqua Rodríguez and Lima 2007) was described.

The selected MDS showed that from an analytical perspective the rice farmers in the region are right in choosing earthworms as an indicator to characterize the quality of their soils; even though they had little practical knowledge as to their populations and how to use them as indicators. When this MDS was used to generate a soil quality index (including earthworm abundance), it significantly distinguished the three rice management systems and different soil textural classes according to basic soil functions (water infiltration, storage and supply; nutrient storage, supply and cycling; and 
sustaining biological activity) showing potential value to indicate soil quality (Lima et al. unpublished data). The index values indicated that the semi-direct management system resulted in the highest overall soil quality, followed by the pre-germinated and conventional systems. This implies that the soil functions considered perform better in the semi-direct management system than in the pre-germinated and conventional systems. None of the other proposed MDS of soil quality (e.g., Doran \& Parkin 1996, Brejda et al. 2000a,b, Govaerts 2006), include earthworms. This is despite the well known positive role of earthworms as ecosystem engineers, acting on the soil's functions (Lavelle et al. 1997), soil physical structure (Lavelle 1988), the decomposition of organic matter and nutrient availability to plants (Brown et al. 2000). However, earthworms can also produce negative effects on soil properties (varying with species and geographic adaptation), acknowledged by a few studies, but ignored by most (Sojka \& Upchurch 1999). For example, earthworms increased bulk density and reduced soil porosity (Alegre et al. 1997) in six successive crops (maize-rice-cowpea-ricerice-rice) and increased crop water stress and consequently reduced yield by $43 \%$ in rice production (Pashanasi et al. 1996).

There is a need for more detailed knowledge about the spatiotemporal distribution of the different species in order to understand the responses of soil earthworm communities to agricultural practices. This is fundamental to the use of individual species and species assemblages as soil quality indicators (Uzêda et al. 2007). In the region studied Ocnerodrilidae were the most diverse (Eukerria saltensis (Beddard 1895), E. eiseniana (Rosa 1895) and E. stagnalis (Kinberg 1867), appearing in all management systems studied. Lumbricidae (Bimastos parvus (Eisen 1874)) were only present in the semi-direct system and the new native genus and species of Criodrilidae ( $G$. $c a$ maqua) was mainly found in the pre-germinated system. The semi-direct appeared to be the most sustainable system and presented the highest earthworm diversity (4 species). The fact that farmers recognized the presence of earthworms as a good indicator for judging soil quality is notorious, but their inability to use them in their decision making in rice management is curious. It seems that because of their actual and previous experience in cropping dry soils (most farmers still have their own horticulture production around their houses) where earthworms are easily visible, they promptly associate earthworms to good soil conditions. But, as in flooded rice fields the earthworms are more difficult to see, they become incredulous of their usefulness for soil quality assessment.

In conclusion, earthworm populations and their diversity can be integral components in evaluating farming systems and can contribute to our understanding of the impact of management systems on sustainability issues. Our study shows that this is particularly true in the rice production systems under investigation.

If appropriately informed, farmers can observe earthworms themselves for decision-making in rice management. Hence, there is a need to develop a decision-sup- 
port system in order to introduce and spread the value of using earthworms as soil quality indicators to irrigated rice farmers. Furthermore, earthworms along with other indicators of the MDS should be considered in assessing the sustainability of rice production management systems.

\section{ACKNOWLEDGMENTS}

The authors thank CAPES (Coordenação de Aperfeiçoamento de Pessoal de Nível Superior - Federal Agency for Post-Graduate Education), Brazil, for financial support. We also extend our thanks to the two reviewers for their great contributions.

\section{LITERATURE CITED}

Alegre, J. C., B. Pashanasi \& P. Lavelle. 1996. Dynamics of soil physical properties in Amazonian agroecosystems inoculated with earthworms. Soil Science Society of America Journal. 60: 15221529.

Ali, A. M. S. 2003. Farmers' knowledge of soils and the sustainability of agriculture in a saline water ecosystem in Southern Bangladesh. Geoderma. 111: 333-353.

Barrios, E. \& M. T. Trejo. 2003. Implications of local knowledge for integrated soil management in Latin America. Geoderma. 111: 217-231.

Birang, M., S. Hauser \& D. L. Amougou. 2003. Farmers' perceptions of the effects of earthworms on soil fertility and crop performance in southern Cameroon. Pedobiologia. 47: 819-824.

Brejda, J. J., T. B. Moorman, D. L. Karlen \& T. H. Dao. 2000a. Identification of regional soil quality factors and indicators: I. Central and southern high plains. Soil Science Society of America Journal. 64: 2115-2124.

Brejda, J. J., D. L. Karlen, J. L. Smith \& D. L. Allan. 2000b. Identification of regional soil quality factors and indicators: II. Northern Mississippi loess hills and Palouse prairie. Soil Science Society of America Journal. 64: 2125-2135.

Bloem, J. \& A. M. Breure. 2003. Microbial Indicators. Pp. 259-282. In: B. A. Markert, A. M. Breure and H. G. Zechmeister (Eds.). Bioindicators and Biomonitors. Principles, concepts and applications. Elsevier, Amsterdam.

Brown, G. G., I. Barois \& P. Lavelle. 2000. Regulation of soil organic matter dynamics and microbial activity in the drilosphere and the role of interactions with other edaphic functional domains. European Journal of Soil Biology. 36: 177-198.

Brown, G. G., N. P. Benito, A. Pasini, K. D. Sautter, M. F. Guimarães \& E. Torres. 2003 No-tillage greatly increases earthworm populations in Paraná state, Brazil. Pedobiologia. 47: 764-771.

Brussaard, L., T. W. Kuyper, W. A. M. Didden, R. G. M. de Goede \& J. Bloem. 2004. Biological soil quality from biomass to biodiversity - Importance and resilience to management stress and disturbance. Pp. 139-161. In: P. Schjønning, S. Elmholt and B. T. Christensen (Eds.). Managing soil quality: challenges in modern agriculture. CABI, Wallingford.

Cunha, N. G., L. F. S. Pinto, R. J. C. Silveira, V. Muller, A. C. R. Lima, C. L. R. Lima, E. L. Santos, R. G. Mendes, M. G. Silva \& M. R. Pereira. 2001. Estudo dos solos do Banhado do Colégio. Embrapa Clima Temperado (Circular Técnica No. 29), Pelotas.

Doran, J. W. \& T. B. Parkin. 1996. Quantitative indicators of soil quality: A minimum data set. Pp. 25-37. In: J. W. Doran and A. J. Jones (Eds.). Methods for assessing soil quality. SSSA Special Publication No. 49. SSSA, Madison. 
Doran, J. W. \& M. R. Zeiss. 2000. Soil health sustainability: managing the biotic component of soil quality. Applied Soil Ecology. 15: 3-11.

Ericksen, P. J. \& M. Ardón. 2003. Similarities and differences between farmer and scientist views on soil quality issues in central Honduras. Geoderma. 111: 233-248.

Govaerts, B., K. D. Sayre \& J. Deckers. 2006. A minimum data set for soil quality assessment of wheat and maize cropping in the highlands of Mexico. Soil \& Tillage Research. 87: 163-174.

Lavelle, P. 1988. Earthworm activities and the soil system. Biology and Fertility of Soils. 6: 237-251.

Lavelle, P., D. Bignell, M. Lepage, V. Wolters, P. Roger, P. Ineson, O. W. Heal \& S. Ghillion. 1997. Soil function in a changing world: the role of invertebrate ecosystem engineers. European Journal of Soil Biology. 33: 159-193.

Lefroy, R. D. B., H. Bechstedt \& M. Rais. 2000. Indicators for sustainable land management based on farmer surveys in Vietnam, Indonesia, and Thailand. Agriculture, Ecosystems and Environment. 81: 137-146.

Lima, A. C. R. \& C. Rodriguez. 2007. Earthworm diversity from Rio Grande do Sul, Brazil, with a new native criodrilid genus and species (Oligochaeta: Criodrilidae). Megadrilogica. 11: 9-18.

Lima, A. C. R., W. B. Hoogmoed \& L. Brussaard. 2008. Soil quality assessment in rice production systems: establishing a minimum data set. Journal of Environmental Quality. 37: 623-630.

Nunes, D. H., A. Pasini, N. P. Benito \& G. G. Brown. 2007. Minhocas como indicadoras da qualidade ambiental. Um estudo de caso na região de Jaguapitã, PR, Brasil. Pp. 467-480. In: G. G. Brown and C. Fragoso (Eds). Minhocas na América Latina: biodiversidade e ecologia. Embrapa Soja. Londrina.

Paoletti, M. G., M. R. Favretto, B. R. Stinner, F. F. Purringon \& J. E. Bater. 1991. Invertebrates as bioindicators of soil use. Agriculture, Ecosystems and Environment. 34: 341-362.

Pashanasi, B., P. Lavelle \& J. Alegre. 1996. Effect of inoculation with the endogeic earthworm Pontoscolex corethrurus on soil chemical characteristics and plant growth in a low-input agricultural system of Peruvian Amazonia. Soil Biology \& Biochemistry. 28: 801-810.

Roming, D. E., M. J. Garlynd \& R. F. Harris. 1996. Farmer-based assessment of soil quality: a soil health scorecard. Pp. 39-60. In: J. W. Doran and A. J. Jones (Eds.). Methods for assessing soil quality. SSSA Special Publication No. 49. SSSA, Madison.

Römbke J., S. Jänsch \& M. Garcia. 2007. Earthworms as bioindicators (in particular for the influence of land use). Pp. 455-466. In: G.G. Brown and C. Fragoso (Eds). Minhocas na América Latina: biodiversidade e ecologia. Embrapa Soja. Londrina.

Soil Survey Staff. 2006. Keys to soil taxonomy. Natural Resources Conservation Service. $10^{\text {th }}$ ed. USDA, Beltsville. $441 \mathrm{pp}$.

Sojka R. E. \& D. R. Upchurch. 1999. Reservations regarding the soil quality concept. Soil Science Society of America Journal. 63: 1039-1054.

Sparling G. P. \& L. A. Schipper. 2002. Soil quality at a national scale in New Zealand. Journal of Environmental Quality. 31: 1848-1857.

Uzêda M. C., M. A. Garcia \& J. R. Costa. 2007. Análise das relações entre populações de enchytraeidae e minhocas e seu uso como bioindicador da qualidade do solo. Pp. 489-495. In: G. G. Brown and C. Fragoso (Eds). Minhocas na América Latina: biodiversidade e ecologia. Embrapa Soja. Londrina. 